\title{
Women Outperform in Computing Education and Compromise in Career Building: An Insight for Policy Makers in India
}

\begin{abstract}
H R Chennamma
Sri Jayachamarajendra College of Engineering, JSS Science and Technology University, Mysuru, INDIA

Abstract : Gender equality in higher education especially in science, engineering and technology is well analyzed issue from past thirty five years. In particular, 'women in computing' has become highly attracted topic due to digital revolution. Gender equality is an expected phenomenon here too. This research work tries to put forth the widely discussed problem of women in computing that is women's increased participation in tertiary education and poor employment rate in IT related fields especially in the Indian scenario. Gender imbalance in IT workforce has been recognized as an issue since at least 2005. Since then the researchers have identified the reasons for underrepresentation of women in IT workforce, even though they outperform in their education. Here we discuss the problem in a new dimension towards providing a better solution. This article provides essential information to policy makers of higher education and has led to the development of important policy interventions, particularly for the retention of women in computing science pipeline.
\end{abstract}

Keywords: Women in computing, Policy makers, Women in IT Sectors, Gender inequality, Higher education

\section{INTRODUCTION}

India emerged as an IT hub of the world (Rohit Bhaskar, 2017). This created a lot of IT related jobs in India. To full fill the needs, universities have started many computing related courses. Gender equity is an expected and natural phenomenon at each level of the academic and employment enterprise. This expected ratio is not balanced in IT workforce though the women enrollment for computing is outnumbered their men counterparts in tertiary education. According to All India Survey of Higher Education the women enrollment for Computer Engineering in India for Post Graduation is 63.9 per cent (AISHE, 2016-2017, T-13). But this does not mean that gender equality has been achieved because women participation in IT industry is only 25 to 30 per cent (Thakkar D, Sambasivan N, Kulkarni P, Kalenahalli Sudarshan P, and Toyama K., 2018). Globally, women made up of 12.2 per cent on board of members in the information technology industry in 2015 (Adams, Renée B., and Kirchmaier T, 2016). Women faculties are a miniscule 7 per cent at prestigious institutes such as IISc and the IITs. Their proportion as INSA fellows is a mere 3.2 per cent (Gupta, N., Kemelgor, C., Fuchs, S., and Etzkowitz, H., 2005). Many researchers have explored the possible reasons for why women fail to build their career in Computer Science. Some of the reasons are:

1. Socio-cultural behavior: gender stereotype

2. Family pattern: disproportionate labor in domestic responsibilities

3. Education system: fail to produce career oriented women

4. Workplace pressure: no flexibility has been given to women who manage both work life during childbearing years.

5. Support from the government: no specific policies which helps to mitigate over responsibilities of women at different stages of life.

We believe that when there are a number of factors and if we do not isolate the factors, then we cannot attack the problem correctly. A famous dictum of Simone de Beauvoir, 'One is not born a woman, but becomes one' (De. Beauvoir S., 1989) her responsibility makes her to think differently from men. If we want more women in technical positions, we need to encourage them by making policies that support to reduce the burden of women in order to increase women participation.

\section{WOMEN OUTPERFORM IN HIGHER EDUCATION}

In the past thirty-five years, women's participation in undergraduate and master's education has increased sharply and steadily. The proportion of women is highest in Medical Sciences (61.2 per cent) and Education (64.1 per cent) at Under Graduation level and consistently increased even in Post Graduation level (refer to Table 1). But male dominates in Engineering and Technology that is 72 per cent. Female participation in this sector is relatively low. Anyhow total female enrolment in higher education constitutes 47.3 per cent (in UG) and 54.6 per cent (in PG) in India (AISHE 2016-17, T$12 \&$ T-13)). Enrolment may not be the gating factor for claiming gender equality. The authors would like to emphasize 


\section{DOI: $10.17148 / I A R J S E T .2021 .8851$}

that the number of female students who pass out the degrees is also outnumbered their male counterparts. According to the statistics, women tend to continue their studies after Under Graduation towards masters.

Women outperform both at UG and PG level in almost all the streams or disciplines (refer to Table 1 and Table 2). Unfortunately, after successful completion of the degree also, women fail to build their career efficiently. Hence, many researches showed that the women are less competent than men. But this statistics show women is more competent in their studies. We would like to state that women are more committed, determinant, and highly focused. Due to lack of encouragement and over burden of responsibilities resulted underrepresentation in workforce. There is a severe leakage while taking computing as a career. The reason could be lack of flexibility to balance their personal life, familial impact and socio-cultural pressure, workplace policies not suited to women, such as marathon coding sessions, flexible work schedule, parental leave and financial support with childcare.

Table 1. Enrolment and pass-out statistics of women at UG and PG Level (courtesy AISHE 2016-17, T-12, T-13, T-35 and T-36)

\begin{tabular}{|l|c|c|c|c|}
\hline & $\begin{array}{l}\text { Enrolment at } \\
\text { UG in per cent }\end{array}$ & $\begin{array}{l}\text { Pass-out at UG } \\
\text { in per cent }\end{array}$ & $\begin{array}{l}\text { Enrolment at Pass-out in per cent } \\
\text { PG }\end{array}$ & $\begin{array}{c}\text { at } \\
\text { PG in per cent }\end{array}$ \\
\hline CS \& E & 43.7 & 51.2 & 57.3 & 60 \\
\hline IT \& Computer & 42.4 & 51 & 50.1 & 53.6 \\
\hline Engineering and Technology & 28.4 & 31.6 & 38.3 & 43 \\
\hline Education & 64.1 & 65.7 & 64 & 62.5 \\
\hline Commerce & 47.5 & 50.7 & 60 & 59.4 \\
\hline Medical Science & 61.2 & 67.5 & 54.9 & 55.9 \\
\hline Science & 47.6 & 50.4 & 60.9 & 61.2 \\
\hline Social Science & 50 & 51.5 & 56.3 & 59 \\
\hline
\end{tabular}

Table 2: Women enrolment and pass-out statistics in various subjects (AISHE 2016-17 T-12, T-13, T-35 and T36)

\begin{tabular}{|l|c|c|c|c|}
\hline & $\begin{array}{l}\text { Enrolment at } \\
\text { UG in per cent }\end{array}$ & $\begin{array}{l}\text { Pass-out at UG } \\
\text { in per cent }\end{array}$ & $\begin{array}{l}\text { Enrolment at } \\
\text { PG in per } \\
\text { cent }\end{array}$ & $\begin{array}{l}\text { Pass-out } \\
\text { PG in } \\
\text { int }\end{array}$ \\
\hline per \\
\hline Law & 37.6 & 41.6 & 39.7 & 40 \\
\hline Home Science & 32.6 & 34.3 & 33.8 & 42.2 \\
\hline Social Work & 83.3 & 78.1 & 90 & 92 \\
\hline Physical Education & 44.8 & 50 & 47.5 & 46.6 \\
\hline Fashion Technology & 30.5 & 30.3 & 25.8 & 28.5 \\
\hline Women Studies & 78.6 & 83.5 & 89.2 & 90.8 \\
\hline Criminology and Forensic Science & 94.3 & 84.2 & 94.4 & 94.4 \\
\hline Journalism and Mass Communication & 62.4 & 70.5 & 46.2 & 43.3 \\
\hline Veterinary and Animal Sciences & 43.8 & 45.6 & 46.4 & 50 \\
\hline Linguistics & 37.1 & 32.6 & 38 & 39.2 \\
\hline Defense Studies & 73 & 77.3 & 82.3 & 86 \\
\hline
\end{tabular}

Furthermore institutional or industrial practices persist that devalue a women's ability with substantial gender disparities in management positions and on boards of directors. National reviews of women's representation in science refer to obstacles relating to the work-life balance and disadvantages to women in science and research who are expected to both manage the household and put in full-time and even overtime at the same rates as men (ECLAC, 2014; Bonder, 2015). Policy makers have to think in this direction that how to reduce the burden of women in order to increase women participation in workforce.

In India, the substantial increase in women undergraduates in Computer Engineering may be indicative of a change in the 'masculine' perception of Computer Engineering in the country (refer to Table 1). But it is highly difficult to find the specific reason for high enrolment in education and low employment rate. The possible reasons could be:

1) Since India has created an impressive number of universities in recent years, there is an easy access of education at their door steps but there is a remarkable shortage of employability to accommodate all graduates. (There are 864 Universities, 40026 Colleges and 11669 Stand Alone Institutions listed on AISHE web portal. 15 


\title{
International Advanced Research Journal in Science, Engineering and Technology
}

\author{
Vol. 8, Issue 8, August 2021
}

\section{DOI: 10.17148/IARJSET.2021.8851}

Universities and 9.3 per cent Colleges are exclusively for women. 59.3 per cent Colleges are located in Rural Area [AISHE 2016-17]).

2) Lack of quality education which suppose to impart skill set among student community to compete in the job market of the world.

3) High enrolment for higher education is may be due to the support and encouragement from parents. But women suffer from deficiency of time to get updated with the new technologies while managing both work life during child bearing years.

\section{RELATED WORK}

In this section, the statistics of women enrolment for graduation in computing and Engineering \& Technology has been collected for significant comparisons between different countries. But the countries have been collected data neither at the same times (or time spans) nor they presented in the same way. For example, in many countries the 'Science' and 'Engineering' encompass different subjects. 'Science' may be defined as encompassing life sciences, physical sciences, and mathematics, statistics and computer sciences; 'Engineering' may include manufacturing and processing, construction and architecture. Since pass-out information has not been available in any standard studies for comparison, only the enrolment statistics has been discussed here. In addition to it, the severe drop outs of women in the computing pipeline while transition from graduation to employment and research has also been compared and discussed.

UNESCO considers gender equality not only to be a fundamental human right but also a building block of sustainable, peaceful societies. This commitment includes promoting a greater participation by women in science, technology, innovation and research. This is why the UNESCO Institute of Statistics systematically collects gender-disaggregated data, which it then makes freely available to the public through interactive websites (UNESCO, 2015). The traditional approach to issues of gender equity in the academy is to examine whether men and women have reached educational and employment parity, a fifty-fifty split, at each level of the academic and employment enterprise.

In Australia, women made up less than one in five students earning degrees in Information Technology (17 per cent) and engineering and related technologies (15.6 per cent). Women accounted for less than one in eight (12.4 per cent) engineers in Australia's labor force in 2016 (Kaspura A, 2017). As of August 2017, women made up less than a quarter (20.7 per cent) of those employed in computer system design and related services (Australia Bureau of Statistics, 2017).

In USA, the percentage of degrees earned by women in computer and information sciences and support services is 18 per cent, 30.4 per cent and 22.5 per cent in Bachelor's, Master's and PhDs respectively. Women made up less than onequarter (24 per cent) of those employed in STEM (Science, technology, Engineering and Mathematics) occupations in 2015 in USA. Women significantly underrepresented in high-tech occupations. In 2016, women accounted for one-fifth (20 per cent) or less of those employed in high-tech occupations. A substantial gender gap in engineering and computer occupations contributes to women's overall underrepresentation in STEM (Ryan Noonan, 2017).

In 2016, undergraduate women in Japan represented just 14 per cent of engineering majors. Only 15.3 per cent of Japan's researchers in science and technology were women (Statistical Handbook of Japan, 2017). Among young Canadians (aged 25 to 34) holding bachelor's degrees in STEM fields, men were almost twice as likely to work in science and technology jobs as women in 2016 . In the same year, women accounted for nearly a quarter (23.1 per cent) of computer and information systems professionals (Statistics Canada, 2017).

At university, Israeli women dominate medical sciences (63 per cent) but only a minority study engineering (14 per cent), physical sciences (11 per cent), mathematics and computer science (10 per cent) (Catalyst, 2018). The flow of Indian students enrolling in science and engineering disciplines in Western universities has increased manifold in recent years. As a result, academic exchanges between Indian and Western nations are very much on the rise. The India stands second in top five foreign student populations in the USA in 2014, they are China (28 per cent), India (12 per cent) and the Republic of Korea ( 8 per cent), Saudi Arabia (6 per cent) and Canada ( 3 per cent), according to the July 2014 quarterly review of the Student and Exchange Visitor Information System published by US Immigration and Customs Enforcement (ICE).

An analysis shows a steady decrease in female graduates in computer science since 2000 that is particularly marked in high-income countries. Exceptions in Europe include Denmark, where female graduates increased from 15 per cent to 24 per cent between 2000 and 2012, and Germany, which saw an increase from 10 per cent to 17 per cent. These are still very low levels. In Turkey, the proportion of women graduating in computer science rose from a relatively high 29 per cent to 33 per cent. Over the same period, the share of women graduates slipped in Australia, New Zealand, the Republic of Korea and USA. The situation in Latin America and the Caribbean is worrying: in all countries reporting data, the 


\title{
International Advanced Research Journal in Science, Engineering and Technology
}

\author{
Vol. 8, Issue 8, August 2021
}

\section{DOI: $10.17148 /$ IARJSET.2021.8851}

share of women graduates in computer science has dropped by between 2 and 13 percentage points. This should be a wake-up call. Female participation is falling in a field that is expanding globally as its importance for national economies grows, penetrating every aspect of daily life(UNESCO, 2015).

Women are consistently least represented in engineering, manufacturing and construction. However, there are regional exceptions: the share of women graduating as engineers in the United Arab Emirates and Palestine (31 per cent), Algeria (31 per cent) and Oman, with an astonishing 53 per cent. Some Asian countries show similar rates: 31 per cent in Viet Nam, 39 per cent in Malaysia and 42 per cent in Brunei Darussalam. The numbers in Europe and North America are generally low: 19 per cent in Canada, Germany and the USA and 22 per cent in Finland, but there are some bright spots: 50 per cent of engineering graduates are women in Cyprus and 38 per cent in Denmark.

Another factor to be considered is women's underrepresentation in research. South Asia is the region where women make up the smallest proportion of researchers: 17 per cent. Of those countries in South Asia reporting data, Nepal has the lowest representation of all at 8 per cent (2010), a substantial drop from 15 per cent in 2002. Only 14 per cent of researchers are women in the region's most populous country, India. The percentage of female researchers is highest in Sri Lanka but has receded somewhat to 37 per cent (2010) from the 42 per cent reported in 2006. Pakistan is gradually catching up (20 per cent in 2013) (UNESCO, 2015).

Another factor to be considered is women's high enrollment in higher education and non persistent in computer related fields. There is a substantial underrepresentation of women in 'computing related jobs'. Almost one-third of women in the United States (32 per cent) and china (30 per cent) intend to leave their SET (Science, Engineering and Technology) jobs within a year. The intension to leave within a year is slightly less common for SET women in Brazil (22 per cent) and India (20 per cent). Work experiences impact women's decisions to leave. Isolation, hostile male-dominated work environments, ineffective executive feedback, and a lack of effective sponsors are factors pushing women to leave SET jobs.

There are exceptions. The Malaysian information technology (IT) sector is made up equally of women and men, with large numbers of women employed as university professors and in the private sector. Additionally, families tend to be supportive of their daughters' entry into this prestigious and highly remunerated industry, in the interests of upward mobility (Mellström, 2009).

\section{IT SECTORS SET UP IN INDIA}

Since 2005 the India is emerged as the world leader for exports of computer and information services and the country's evolution rose into a hub for 'frugal innovations' (Sunil Mani, 2014).

Today, India's economy is dominated by the services sector, which represents 57 per cent of GDP, compared to 25 per cent for industry, half of which comes from manufacturing (13 per cent of GDP in 2013). So, Indian IT industries need to work according to foreign timings. This is a setback for women to work in different shifts of office hours. This is a daunting factor for one who balances work and household with rising children especially in Indian scenario.

Anyhow, industry has complained of severe shortage of skilled personnel (UNESCO, 2015). The government has instigated a variety of schemes over the past decade to correct these imbalances. The next part of this paper will be devoted to understand, how effective these schemes have been.

\section{POLICIES FOR TERTIARY EDUCATION AND WOMEN EMPOWERMENT}

The growth of any country must need talent, creativity and accomplishments of both sexes. Overall, this section provides information about the policies to improve the quality of higher education and research and detailed analysis of the relationship between the expansion of women's participation in higher education, and the changes made in women's lives. The lack of information about current opportunities and possibilities may lead to inappropriate policies and plans, an understanding of the effects of these changes for women and the way in which they can influence women's lives and general social attitudes, has the potential to improve national policies in various fields such as education and employment.

Now business executives and bureaucrats are strongly in favor of increasing the number of skilled workers, particularly in the software industry. At the same time, the Indian government is investing heavily in building world-class research facilities to nurture the skill set among the students community.

In June 2014, the Indian Institution of Engineers became a signatory of the Washington Accord. The Washington Accord is an international agreement by which bodies responsible for accrediting engineering degree programme recognize the graduates of other signatory bodies as having met the academic requirements for entry into the engineering profession. This recognition offers future Indian engineers easy mobility throughout the signatory countries. In addition to it, the 


\title{
International Advanced Research Journal in Science, Engineering and Technology
}

\author{
Vol. 8, Issue 8, August 2021
}

\section{DOI: $10.17148 /$ IARJSET.2021.8851}

government has put in place a number of remedial measures to improve the quality of higher education. These include a stricter control over universities, regular audits of the curriculum and facilities and faculty improvement programs.

The shortage of R\&D personnel could hold India back on its climb up the technology ladder. If you take a group of 100 researchers in India, 46 will work for the government, 39 for industry, 11 for academia and 4 for the private non-profit sector. This makes the government the main employer. The government sector also spends the majority of the R\&D budget (60 per cent), compared to 35 per cent for industry and just 4 per cent for universities. Policy-makers are fully cognizant of this problem and have been putting in place a host of policies to boost research enrolment in science and engineering programme. One of these schemes, INSPIRE, focuses in particular on developing a vocation for science among the young (DST, India, 2018)..

The Indian Constitution guarantees equality of pay and prohibits discrimination; yet there is little recognition of discrimination against women scientists. There is only a single point on the agenda of 'Science and Technology for Women' in 'Science and Society Programmes' of the Department of Science and Technology (DST) concerning women scientists. However, DST has introduced a scheme enabling women to reenter their career in science after a break. Compilation of the recent report by INSA on women in science is a significant step to gather information, without which bias cannot be understood. However, much more needs to be done. Since 2009, the DST has improved research infrastructure at six of India's universities for women, via the consolidation of university research for innovation and excellence (CURIE) programme. Government has sanctioned six months of maternity leave recently. Single girl child will get financial support through scholarships from the government. DST has schemes to provide fellowships for women scientists (DST, India, 2018).

Women's rights both inside and outside the home must be strengthened and the participation of women and girls in education and employment must be encouraged through proper policies. It is needed to introduce policies for promoting the training and employment of citizens, as well as a greater participation of women in the labor force. There must be equal opportunities for men and women in education, training and employment in scientific and technical fields. Government should offer fellowships and awards for institutional transformation and leadership to increase the participation of women in research and reward excellence.

Policies are needed to provide job security for the women who with draw from the labor force to take care of children and change the current system of performance appraisal and reward to accommodate women's child-bearing years without obliging them to sacrifice their careers is the single most important step towards rectifying this imbalance. Policy makers have to analyze the persistent problems in recruiting and retaining undergraduate women in computer science.

\section{GENDER THEORY OF WOMEN: GRADUATION TO OCCUPATION}

The literature on women's enrolment and retention in computer-related majors begs the question of 'Which Women?' According to statistics (refer to Table 1 and Table 2), in computing higher education women's enrolment as well as pass out percentage is greater than male. Surprisingly when it comes to occupation or workforce, male dominates women. This raises a question of where all educated 'Brains Disappear' in labor force or are all 'Brains Buried' at home, (this is also called 'Domestic Drain Brain') (Kim, Y. \& Y. Moon, 2011). There are four factors which influences on retention of women in workforce. They are education system, family pattern, work environment, and government policies.

The shortage of women in computer science has serious consequences for women's education and for the loss of productivity and innovation necessary for the advancement of science and technology (National Center for Women \& Information Technology 2005) Changes in women's rights through educational achievements have increased gender equality through society, including in family life. These changes have been heralded as transforming women's opportunities to control and shape their personal lives (Goldin \& Katz, 2008). In family relations, based on a social partnership of interdependence and mutual adjustment, couples can decide how to divide their labor most effectively to satisfy personal needs and family responsibilities, which does not require that all duties be split evenly down the middle. Today, women have more control over the course and rhythm of their lives than ever before, but they also struggle with more choices about how to achieve self-fulfillment.

Education has different effects on measurable characteristics such as employment rate, marriage, childbearing, and income; however, these factors do not fully explain the effects of increase in women's higher education participation. Higher education alters the individual's traditional norms and values by developing modern values such as 'openness to new ideas,' 'independence from traditional authority,' 'willingness to plan and calculate future exigencies,' and 'a strong sense of personal and social efficacy’ (Benavot, 1989, p. 16). Anyhow, when a significant amount of the population is exposed to modernizing institutions such as universities, the level of individual modernity increases and the educational expansion affects the economic development through its effects on individual beliefs and values (Brown \& Lauder, 2006). 


\title{
International Advanced Research Journal in Science, Engineering and Technology
}

\author{
Vol. 8, Issue 8, August 2021
}

\section{DOI: $10.17148 /$ IARJSET.2021.8851}

The assimilated modernization ideology enabling women to take up higher education, but traditional gender role expectations and a rigid structure at the workplace constitute barriers to women for managing both home and career successfully.

In India, educational decisions are family decisions. Though science and engineering degrees bring in greater prestige and job opportunities, most families are less inclined to invest family resources on academic achievements of daughters than sons. It is assumed that after marriage, benefits of their education would accrue to their husbands and their family. Many parents have an apprehension that it is difficult to find a suitable match with higher educational qualification and age.

Different stages of Women's life are orthogonal to each other with respect to her responsibilities and free time. Women's free time may be disproportionately limited due to employment obligations and housework. Women reported lower levels of colleagueship and reciprocation in the department relationships than do their male peers and typically lack strong networks essential for academic success in the department.

Due to lack of free time, women constitute only 29 percent of Internet users in India, despite making up nearly half the population. There could be other reasons for women are less likely than men to own a mobile phone or go online. They are lower purchasing power, lower technical literacy, limited physical mobility, and prevailing discriminatory practices prevent many women from accessing smartphones.

In India, traditional norms add to the social obligations due to marriage, and women have greater domestic responsibilities than their spouses. Women publish papers more after the age of 50 years, which indicates that they often postpone rigorous research to take care of the family. There is exhaustion in managing a home and career. Women lack time for informal communication and activities that lead to building up of contacts. Women have to often forego opportunities to travel regarding assignments, conferences, etc. Often they scale down their ambitions to accommodate their family.

Exclusion from administration deprives women of a chance to build up contacts, to prove themselves, and to make the administration more gender-sensitive. They have to work hard to prove their capabilities due to gender stereotypes in the work environment.

To find acceptance among the scientific community, some women scientists continue to follow the traditional path of attaining success in science, which is a 'male model' requiring full time devotion to research, early achievement and exclusive identification of oneself with science. However, most women find this model difficult to follow due to their need for diverse identities and marriage-family concerns. This has resulted in the emergence of two sub-groups among women scientists - 'instrumentals' and 'relationals'. The 'instrumentals' are usually older women scientists who conform to the traditional 'male model' and equate gender issues with a lack of commitment to science. 'Relationals' are a new cohort of female faculty who emphasize collaboration and community within their research group and are sensitive to gender bias. Such groupism tends to confuse the issue of achieving legitimacy for different paths of attaining success in science.

\section{CONCLUSION}

Gender equality is more than a question of justice or equity. Countries' industries and institutions should create an enabling environment for women to increase their innovative capacity and competitiveness. The scientific endeavor benefits from the creativity and vibrancy of the interaction of different perspectives and expertise. Gender equality will encourage new solutions and expand the scope of research. Although more women are studying for degrees related to health, science and agriculture than before and there is even a gender imbalance in favor of women at the tertiary level overall, the sheer drop in female researchers to less than 30 per cent globally indicates that serious barriers remain to the full participation of women in science and engineering. At the transition from master's to PhD level then, as they climb the rungs of the career ladder, a number of women are 'lost' in the pipeline.

Even women who embark on a career in science or engineering often leave their jobs for family reasons or change career paths more often than men. Anyhow, retaining women in IT career will likely be difficult, it may take time (possibly decades) for those improvements to translate into IT job parity.

\section{REFERENCES}

1. Adams, Renée B., \& Tom Kirchmaier. "Women on Boards in Finance and STEM Industries† $\dagger$." American Economic Review: Papers \& Proceedings 2016, 106(5), pp. 277-281, 2016.

2. AISHE, 2016-17, (All India Survey on Higher Education), Government of India, Ministry of Human Resource Development, Table 12, Table 13, Table 35 \& Table 36:, p. T-12, T-13, T-35 \& T-36. 


\title{
International Advanced Research Journal in Science, Engineering and Technology
}

\author{
Vol. 8, Issue 8, August 2021
}

DOI: $10.17148 /$ IARJSET.2021.8851

3. Australia Bureau of Statistics, Table 6: Employed Persons by Industry Sub-Division of Main Job (ANZSIC) and Sex, 6291.0.55.003 Labour Force, Australia, Detailed, Quarterly, August 2017, Time Series Spreadsheets, 2017.

4. Beauvoir, Simone de. (1989, c1952) The second sex /New York, Vintage Books.

5. Benavot A, Education, Gender, and Economic Development: A Cross-National Study, Sociology of Education 62(1), 1989.

6. Bonder, G. National Assessments of Gender, Science, Technology and Innovation: Argentina. Women in Global Science and Technology and the Organization for Women in Science for the Developing World: Brighton (Canada), 2015.

7. Brown, P. and Lauder, H., Globalisation, Knowledge and the Myth of the Magnet Economy, Globalisation, Societies and Education, 4(1), pp. 25-57, 2006

8. Catalyst, (2018, January 3), Quick Take: Women in Science, Technology, Engineering, and Mathematics (STEM), Retrieved from https://www.catalyst.org/knowledge/women-science-technology-engineering-and-mathematics-stem\#footnote11_qt42nfg

9. Department of Science and Technology (DST), India, (2018, October 14), Retrieved from, http://www.dst.gov.in/scientificprogrammes/scientific-engineering-research/women-scientists-programs.

10. ECLAC The Software and Information Technology Services Industry: an Opportunity for the Economic Autonomy of Women in Latin America. United Nations Economic Commission for Latin America and the Caribbean: Santiago, 2014.

11. Goldin C and Katz L., The Race Between Education and Technology. Belknap Press for Harvard University Press, 2008.

12. Gupta, N., Kemelgor, C., Fuchs, S., \& Etzkowitz, H. Triple burden on women in science: A cross-cultural analysis. Current Science, 89(8), $1382-1386,2005$.

13. Kaspura A, (2017, March 21), The Engineering Profession: A Statistical Overview (Thirteenth Edition): p. 32.

14. Kim, Y. and Y. Moon National Assessment on Gender and Science, Technology and Innovation: Republic of Korea. Women in Global Science and Technology: Brighton (Canada), 2011.

15. Mellström U, The Intersection of Gender, Race and Cultural Boundaries, or Why is Computer Science in Malaysia Dominated by Women? Social Studies of Science, 39(6), pp. $885-907,2009$.

16. National Center for Women Information Technology, Retrieved http://www.ncwit.org/sites/default/files/resources/ncwitscorecard_07312014_lowres.pdf, 2014.

17. Rohit Bhaskar, (2017, November 21) A look at India's journey to become the IT hub of the world. Retrieved from https://in.pcmag.com/india-3/117676/feature/a-look-at-indias-journey-to-become-the-it-hub-of-the-world.

18. Ryan Noonan, Women in STEM: 2017 Update (2017, November 13), US Department of Commerce, Economics and Statistics Administration, Office of the Chief Economist.

19. Statistical Handbook of Japan, Statistics Bureau, Ministry of Internal Affairs and Communication, Chart 4: Number of Female Researchers (Head Count), Survey of Research and Development: Summary of Results, 2017.

20. Statistics Canada, Is Field of Study a Factor in the Earnings of Young Bachelor's Degree Holders? Census in Brief, 2017.

21. Sunil Mani, (2014, December 06), Economic \& Political Weekly, Emergence of India as the World Leader in Computer and Information Services Vol. 49, Issue No. 49.

22. Thakkar D, Sambasivan N, Kulkarni P, Kalenahalli Sudarshan P, \& Toyama K. The Unexpected Entry and Exodus of Women in Computing and HCI in India. In Proceedings of the 2018 CHI Conference on Human Factors in Computing Systems, paper no. $352,2018$.

23. UNESCO science report: towards 2030, by United Nations Educational, Scientific and Cultural Organization. 2015.

24. Ms. Ritu; Preeti Chawla. "Indian Environment for Entrepreneurship: A Study based on Literature Review". International Research Journal on Advanced Science Hub, 3, Special Issue ICIES-2021 4S, 2021, 18-21. doi: 10.47392/irjash.2021.104

25. Meenakshi Sundaram K.. "National Education Policy 1986 Vs National Education Policy 2020 - A Comparative Study". International Research Journal on Advanced Science Hub, 2, Special Issue ICAMET 10S, 2020, 127-131. doi: 10.47392/irjash.2020.210 